\title{
IMPLEMENTATION OF LINEAR CONGRUENT METHOD (LCM) ALGORITHM AS A TRAFFICER FOR FAHMIL QUR'AN
}

\author{
Gusti Alfyansyah (1), Bustami ${ }^{(2)}$, Fadlisyah(3) \\ Informatics Engineering Study Program, Malikussaleh University \\ Kampus Bukit Indah, Blang Pulo, North Aceh, Indonesia \\ Email :gustialfyan03@gmail.com
}

\begin{abstract}
Abstrak-Fahmil Qur'an is one of the branches of the Musabaqah Tilawatil Qur'an (MTQ) race. In the Fahmil Quran race, the participants will be given a package of questions - questions that will be tested by the participants' ability to work together when answering questions given by the jury. And the package of questions that are available is printed poorly, allowing the jury to misrepresent the participants. To avoid repetition in giving questions to participants, a system will be built that is able to randomize the questions automatically. Randomizing the question uses a linear congruent method algorithm. In this research there is a system flowchart and manual calculation of the linear congruent method algorithm.
\end{abstract}

Kata Kunci : Algorithms, Linear Congruent Method, Fahmil Qur'an

\section{Introduction}

Musabaqah Tilawatil Qur'an (MTQ) has existed in Indonesia in the 1940s since the establishment of Jami'iyyatul Qurro wal Huffadz which was founded by Nahdlatul Ulama, the largest mass organization in Indonesia. Since 1968, when the Minister of Religion was still held by K.H. Muhammad Dahlan (one of the leaders of the Nahdlatul Ulama Executive Board) MTQ was instituted nationally. It can be said that MTQ is a routine activity in religious activities, and that is quite large funded by the current government. This activity will be held annually both formally and 
formally, the event organized makes a privilege that must be proud of and preserved.

This activity includes various kinds of competitions namely mensyi'arkan dakwah, the art of painting verses - the holy verses of al qur'an which are often called calligraphy and the most awaited - waiting is the fahmil quran race.

Fahmil Qur'an is one of the branches in the implementation of MTQ, Fahmil Qur'an, which is a type of competition that relies on the knowledge and understanding of verses, knowledge and content and content in the Islamic holy book, the Qur'an. In this competition, the Fahmil Qurans jury will give questions to each team by reading out some of the available question packages that are printed poorly, making the judges inefficient in giving questions to participants of the Fahmil quran. For now there is no system that can alleviate the problems faced by the Fahmil Quran jury.

Therefore, the author took the initiative to make the "Fahmil Qur'an Randomization System Using the Linear Congruent Method Algorithm" in order to facilitate the jury in giving questions automatically and randomly.

\section{Research Methods}

An algorithm is an unambiguous sequence of instructions to solve a problem, namely to get the required results for each logical input in a certain period of time. Algorithms are sequences of logical steps to solve problems arranged systematically.

The LCM (Linear Congruent Method) algorithm is a process of randomly reducing the value of uncertain variables to simulate a model. Linear Congruent Method aims to generate random variables through sampling from probability distributions. [3] Linear Congruent Method is defined in the equation as follows:

$X \mathrm{n}=(a \times X \mathrm{n}-1+b) \bmod m$ 
Formula (1) is a formula used in calculating the value of a random variable through sampling from a probability distribution. Here's the statement:

$n=$ natural number

$X \mathrm{n}=\mathrm{nth}$ random number from the sequence

$X \mathrm{n}-1=$ previous random number

$a=$ multiplier

$b=$ increment

$m=$ modulus

The generator key is $X 0$ which is the first value that appears at randomization which is obtained randomly. LCM has a period not greater than $\mathrm{m}$, and in most cases the period is less than that. LCM has a full period $(m-1)$ if it meets the following conditions:

1. $b$ relatively prime with $m$.

2. $a-1$ can be divided by all prime factors of $m$

3. $a-1$ is a multiple of 4 if $m$ is a multiple of 4

4. $m>\operatorname{maks}(a, b, X 0)$

5. $a>0, b>0$

Although LCM is theoretically capable of producing decent random numbers, it is very sensitive to the selection of values $a, b$, and $\mathrm{m}$. the selection of inappropriate values can affect the implementation of the LCM.

\section{Results and Discussion}

\subsection{Flowchart System}

In making a program there needs to be a way to analyze a case that will be made a program with one programming language to analyze a case by using a Flowchart. Flowchart is a set of certain images to express the flow of a program that will be translated into one programming language. The use of flowcharts is the same as an algorithm that is to write down the flow of the program but in the form of images or symbols. 


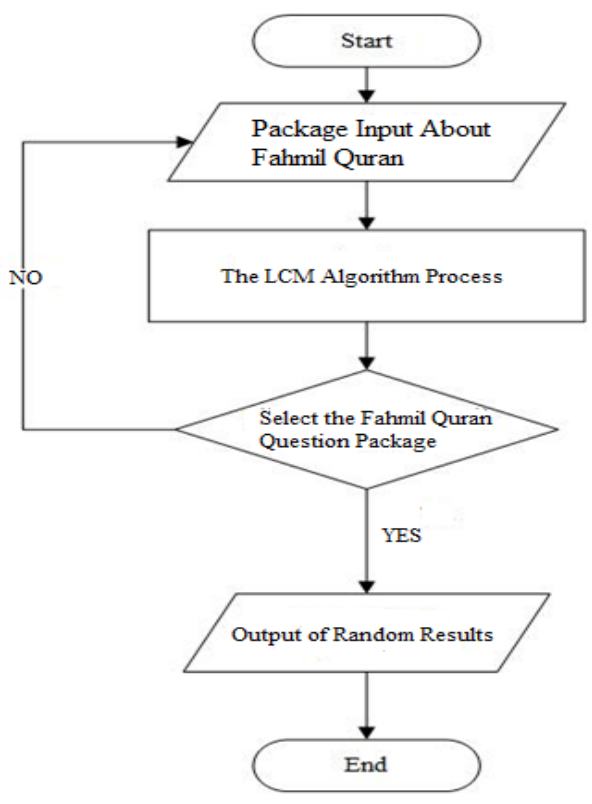

Picture 1. Flowchart system

\subsection{Manual Calculation}

Scrambles the package questions in the system that have 25 questions. Following are the steps or steps for manual calculation using the Linear Congruent Method algorithm:

In accordance with the above conditions to get the full period from the LCM, specify:

$a=6$

$b=11$

$m=25$ (number of questions to be randomized)

$X 0=1$ (taken by random process).

Check compliance:

1. $b$ relatively prime with $m$

$b=11$ is relatively prime to $m=25$

2. $a-1$ can be divided by all prime factors of $m$

$6-1=5$ can be divided by all prime factors of 25

3. $a-1$ is a multiple of 4 if $\mathrm{m}$ is a multiple of 4 
$m=25$ is not a multiple of 4

4. $m>\operatorname{maks}(a, b, X 0)$

$25>\operatorname{maks}(6,11,1)$

5. $a>0, b>0$

$6>0,11>0$

Requirements fulfilled, then the next step is to calculate the randomization process according to the formula:

$X 0=1$ (randomly taken)

Following is the calculation table:

Table 1. Calculation Results

\begin{tabular}{|c|c|c|}
\hline No & $\mathbf{X}_{\mathbf{n}}=\left(\mathbf{a} \cdot \mathbf{X}_{\mathbf{n}-1}+\mathbf{b}\right) \bmod \mathbf{m}$ & Hasil Random \\
\hline 1 & $\begin{array}{c}X_{1}=\left(6 . X_{0}+11\right) \bmod 25 \\
=(6.1+11) \bmod 25\end{array}$ & 17 \\
\hline 2 & $\begin{array}{c}X_{2}=\left(6 . X_{1}+11\right) \bmod 25 \\
=(6.17+11) \bmod 25\end{array}$ & 13 \\
\hline 3 & $\begin{array}{c}X_{3}=\left(6 . X_{2}+11\right) \bmod 25 \\
=(6.13+11) \bmod 25\end{array}$ & 20 \\
\hline 4 & $\begin{array}{c}X_{4}=\left(6 . X_{3}+11\right) \bmod 25 \\
=(6.14+11) \bmod 25\end{array}$ & 6 \\
\hline 5 & $\begin{array}{c}X_{5}=\left(6 . X_{4}+11\right) \bmod 25 \\
=(6.20+11) \bmod 25\end{array}$ & 22 \\
\hline 6 & $\begin{array}{c}X_{6}=\left(6 . X_{5}+11\right) \bmod 25 \\
=(6.6+11) \bmod 25\end{array}$ & 18 \\
\hline 7 & $\begin{array}{c}X_{7}=\left(6 . X_{6}+11\right) \bmod 25 \\
=(6.22+11) \bmod 25\end{array}$ & 19 \\
\hline 8 & $\begin{array}{c}X_{8}=\left(6 . X_{7}+11\right) \bmod 25 \\
=(6.18+11) \bmod 25\end{array}$ & 0 \\
\hline 9 & $\begin{array}{c}X_{9}=\left(6 . X_{8}+11\right) \bmod 25 \\
=(6.19+11) \bmod 25\end{array}$ & 11 \\
\hline 10 & $\begin{array}{c}X_{10}=\left(6 . X_{9}+11\right) \bmod 25 \\
=(6.0+11) \bmod 25\end{array}$ & \\
\hline
\end{tabular}


Table 1 (Continued)

From the table above calculation has been obtained random results which are 17, 13, 14. 20, 6, 22, 18, 19, 0, 11, 2, 23,24, 5, 16, 7, 3, 4, 10,

\begin{tabular}{|c|c|c|}
\hline 11 & $\begin{array}{c}X_{11}=\left(6 . X_{10}+11\right) \bmod 25 \\
\quad=(6.11+11) \bmod 25\end{array}$ & 2 \\
\hline 12 & $\begin{aligned} X_{12} & =\left(6 . X_{11}+11\right) \bmod 25 \\
& =(6.2+11) \bmod 25\end{aligned}$ & 23 \\
\hline 13 & $\begin{array}{c}X_{13}=\left(6 . X_{12}+11\right) \bmod 25 \\
=(6.23+11) \bmod 25\end{array}$ & 24 \\
\hline 14 & $\begin{array}{c}X_{14}=\left(6 . X_{13}+11\right) \bmod 25 \\
\quad=(6.24+11) \bmod 25\end{array}$ & 5 \\
\hline 15 & $\begin{aligned} X_{15} & =\left(6 . X_{14}+11\right) \bmod 25 \\
& =(6.5+11) \bmod 25\end{aligned}$ & 16 \\
\hline 16 & $\begin{array}{c}\mathrm{X}_{16}=\left(6 . \mathrm{X}_{15}+11\right) \bmod 25 \\
=(6.16+11) \bmod 25\end{array}$ & 7 \\
\hline 17 & $\begin{aligned} X_{17} & =\left(6 . X_{16}+11\right) \bmod 25 \\
& =(6.7+11) \bmod 25\end{aligned}$ & 3 \\
\hline 18 & $\begin{array}{c}X_{18}=\left(6 . X_{17}+11\right) \bmod 25 \\
=(6.3+11) \bmod 25\end{array}$ & 4 \\
\hline 19 & $\begin{aligned} X_{19} & =\left(6 . X_{18}+11\right) \bmod 25 \\
& =(6.4+11) \bmod 25\end{aligned}$ & 10 \\
\hline 20 & $\begin{aligned} X_{20} & =\left(6 . X_{19}+11\right) \bmod 25 \\
& =(6.10+11) \bmod 25\end{aligned}$ & 21 \\
\hline 21 & $\begin{array}{c}X_{21}=\left(6 . X_{20}+11\right) \bmod 25 \\
=(6.21+11) \bmod 25\end{array}$ & 12 \\
\hline 22 & $\begin{array}{c}X_{22}=\left(6 . X_{21}+11\right) \bmod 25 \\
\quad=(6.12+11) \bmod 25\end{array}$ & 8 \\
\hline 23 & $\begin{aligned} X_{23} & =\left(6 . X_{22}+11\right) \bmod 25 \\
& =(6.8+11) \bmod 25\end{aligned}$ & 9 \\
\hline 24 & $\begin{array}{c}X_{24}=\left(6 . X_{23}+11\right) \bmod 25 \\
\quad=(6.9+11) \bmod 25\end{array}$ & 15 \\
\hline 25 & $\begin{array}{c}X_{25}=\left(6 . X_{24}+11\right) \bmod 25 \\
\quad=(6.15+11) \bmod 25\end{array}$ & 1 \\
\hline
\end{tabular}

$21,12,8,9,15,1$. There is no repetition of the same value that is processed. Linear Congruent Method is capable of producing 
decent random numbers, but is very sensitive to the selection of values $a, b$, and $m$. the selection of inappropriate values can affect the implementation of this method.

\section{Conclusions}

In closing the discussion in this journal, the author concludes, that in applying linear congruent method (LCM) for randomizing questions, there are things that must be considered. The use of constants $\mathrm{a}, \mathrm{b}$, and $\mathrm{m}$ strongly determines the randomization that occurs so that with the right combination of constants it will produce randomization of really random questions. In designing randomization questions, there are several things that must be considered. Data and methods used in the system. The linear congruent method works as a scrambler so that each question has a different problem. 


\section{Bibliography}

Afrian. 2014. Perancangan Aplikasi Game Asah Otak Tebak Kata Berbasis Android Dengan Menggunakan Metode Linear Congruent Method (LCM). Pelita Informatika Budi Darma, Volume VI No 1.

Indonesia, Universitas. 2015. Musabaqah Fahmil Qur,an. http://mtqmn14.ui.ac.id/musabaqah-fahmil-al quran.html. Diakses Tanggal 21 Juni 2019.

Munir, Renaldy, 2002, Algoritma dan Pemrograman dalam Bahasa Pascal dan C. Informatika, Bandung.

Nurjanah, Peta, Ernawati. 2017. Implementasi Algoritma Linear Congruent Method Dan Algoritma Suffix Tree Pada Aplikasi Casual Game Tebak Lagu. Jurnal Rekursif.

Setiawan, Rony, 2009, Teknik Pemecahan Masalah Dengan Algoritma Dan Flowchart. Jakarta. 